\title{
11 Federalism and the COVID-19 crisis
}

\section{Center-state apposite relations in India}

\author{
Rekha Saxena
}

\subsection{Introduction}

The COVID-19 pandemic around the world has put both healthcare and federal structures to the test. A key feature of India's response to the COVID-19 outbreak has been the close collaboration and cooperation between the Union (central) and state governments. The pandemic has underlined the necessity for strengthening cooperative federalism since no single jurisdiction or level of government has the capability to deal with the crisis on its own. In India, as in most federations, the constitution lists healthcare a responsibility assigned to state governments. In extraordinary circumstances such as the outbreak of COVID-19, the constitution provides for the Union government to take the lead in coordinating between and supporting the states. The legal framework for these interventions is provided by two laws, the 1897 Epidemic Diseases Act and the 2005 Disaster Management Act (Table 11.1).

\subsection{COVID-19 first wave in India}

During the first phase of the pandemic, India began with a very stringent and rigid lockdown in the months of March-April-May 2020 and then in subsequent months, unlocking measures to protect the economy and prevent the livelihood crisis of Indians in itself invites a case study. As of January 2021, India stands as the seventh most affected country in the world if we consider the number of active cases country-wise. However, fatalities and total cases put India third and second respectively. While the recovery rate in India is on a persistent improvement rate ( 94.74 percent), the fatality rate is at 1.45 percent. The rise in active cases has varied across the states/UTs. From Maharashtra to Kerala to West Bengal and then to Delhi, the rise in caseload has continuously varied. The states/UTs with worst fatality rates have been Punjab (3.15 percent), Maharashtra (2.57 percent), and Gujarat (2.23 percent). As many as

Table 11.1 Key Statistics on COVID-19 in India as of 10 January 2021

\begin{tabular}{lllll}
\hline $\begin{array}{l}\text { Cumulative } \\
\text { Cases }\end{array}$ & $\begin{array}{l}\text { Cumulative Cases per } \\
100,000 \text { Population }\end{array}$ & $\begin{array}{l}\text { Cumulative } \\
\text { Deaths }\end{array}$ & $\begin{array}{l}\text { Cumulative Deaths per } \\
100,000 \text { Population }\end{array}$ & $\begin{array}{l}\text { Case Fatality } \\
\text { Percentage }\end{array}$ \\
\hline $10,450,284$ & 757.3 & 150,999 & 10.9 & 1.4 \\
\hline
\end{tabular}

Source: World Health Organization Weekly epidemiological update - 12 January 2021. Geneva: WHO, 2021. Available from https://www.who.int/publications/m/item/weekly-epidemiological-update 
13 states have witnessed their fatality rates higher than the national average. While Maharashtra has been the most affected states, the southern states of Karnataka, Andhra Pradesh, Tamil Nadu, and Kerala have followed with most affected states. Despite that, there is another level of variation when it comes to highest test positivity rate (percentage of tested people turning out to be positive for COVID-19 infection). Though Maharashtra with 16.29 percent still leads the pack, it is followed by the Goa (13.45 percent), Chandigarh (11.77 percent), Nagaland (9.96 percent), and Kerala (9.62 percent). However, highest number of tests per million population has been carried out the most into Delhi, Jammu and Kashmir, Andhra Pradesh, Karnataka, and Kerala (Business Standard 2020).

The Center has allowed the states to devise ways for the safe reopening of the schools and coaching centers post mid-October. However, such a move needed to be given a second thought given the high prevalence of COVID-19 infections among children in the states of Tamil Nadu and Andhra Pradesh. How viable would the unlocking measures be in improving the lives of the people would witness the test of times as continued transmission is still witnessed in the states of Kerala and Tamil Nadu due to careless attitudes among the people. The fifth round of India's unlockdown in October 2020, also called unlock 5.0, further extended the opening of activities in the fields of education, entertainment cinema, and business conferences. This was allowed at the time when the rise of COVID-19 cases was still high in many cities. Although the new cases of infection are still piling up, the country witnessed a decline in the case load compared to the previous months, especially during July, August, and September (Johns Hopkins Coronavirus Resource Center 2021). What is unique and uncommon in the case of India is the two varied line of measures adopted in dealing with the pandemic.

\subsection{COVID-19 and federalism in India}

The 1897 Epidemic Diseases Act constitutionally empowers both the central and state governments to regulate the spread of epidemic diseases. According to the act, the Union is empowered to take preventive steps with respect to epidemic diseases at ports of entry and exit. At the same time, it also empowers the state governments to take preventive and regulatory measures to curb the spread of epidemic diseases within their own jurisdiction. Consequently, the act enables states to impose bans on public gatherings, close educational institutions including schools, colleges, and universities, and instruct companies to devise work-from-home strategies within their territories. The state of Karnataka became the first to invoke the act and put the powers assigned under it into action on 11 March 2020. The states of Haryana, Maharashtra, Delhi, and Goa followed suit shortly thereafter. In due course of time, consequently, the central government also asked all the states to invoke provisions of section 2 of the act, so that health ministry advisories could become enforceable.

Another significant act is the 2005 Disaster Management Act. Constitutionally, Disaster Management is part of residuary power of legislation which according to Article 248 of the 1949 Constitution of Indian rests with the Parliament of India. While the 2005 Disaster Management Act was brought out through entry 23 of the concurrent list namely, "Social security and social insurance, employment and unemployment," it was framed to deal with disasters at both central and state levels. It was 
on 14 March that the Union government classified COVID-19 as a "notified disaster." The act empowers both the central and state governments to impose a complete lockdown and regulate movement of people.

In India, as in most federations, the constitution lists healthcare a responsibility assigned to state governments. In extraordinary circumstances such as the COVID-19 outbreak, the constitution provides for the Union government to take the lead in coordinating between and supporting the states. In hindsight, the initial response of the center, as evident from the pan-India imposition of the first and second phases of lockdown without making any consultation with State governments, had appeared to be centralizing. The all-pervasive notifications and guidelines issued by Union had only encroached upon areas strictly falling within the domain of the State (State list in 7th Schedule of the Constitution). This included the State government offices (Entry 41), hospitals (Entry 6), shops and markets (Entry 28), industries (Entry 24), agriculture (Entry 14), etc., the encroachment of which ultimately paralyzed State finances.

However, an argument can be made that gradually, through Prime Minister's video meetings with various Chief Ministers, Administrators and Lieutenant Governors, inputs and suggestion were sought from states. This signified the larger reinvigoration of leeway of the state. Moreover, when it comes to easing of restrictions and extending relaxations, lockdown 4.0 was different from the earlier ones. In contrast from the earlier lockdown phases, states were given greater autonomy, for example, with respect to classification of red, orange, and green zones, respectively. Furthermore, states could also seal their borders (e.g., UP, Haryana, and Karnataka) to restrict the entry of people from other states in order to contain the outbreak. With the onset of new phase Unlock 1.0 from 1 June 2020, both center and state started to play a pivotal role in further opening up the economy with alacrity. More autonomy was extended to States in declaring any area as buffer zone within their territories and thereupon impose containment restrictions.

From the standpoint of executive federalism, it was fascinating to see India's attempt to handle this pandemic through an executive order, which has been in line with similar approaches adopted by many federal countries. All previously enacted laws have been used to deal with the situation. The Legislature did not come into the picture unnecessarily.

The more apprehensible understanding of federal framework requires light not only on extant division of powers between center and states but also on available laws for containing the outbreak. In the majority of the federal countries, including India, the constitution lists healthcare as a responsibility of state governments, but during pandemics, when the life of citizens is at stake, the central government takes up an upbeat role as witnessed in the event of lockdown which in turn, however, has exacerbated the economy. Since 'economic and social planning' is in the concurrent list, it is the central government that assumed responsibility for the overall management of the economy amidst this lockdown.

\subsection{Responses to the first wave}

The slugfest of efforts that various levels of governments have put in containing the pandemic is in themselves noteworthy. The central government has persistently widened the COVID-19 testing and made interventions in the economic sector to alleviate 
the growing public concerns. The announcement of a financial support package worth USD 22.6 billion to help people during the crisis was one of those interventions. This stimulus included free food grains and cooking gas for the poor for three months (which was later extended for another five months) and cash incentives to women and poor senior citizens for the same period.

The simultaneous efforts of the various states and the innovative ways that they adopted in dealing with the pandemic also call for appraisal. In terms of declaring relief measures, steps taken by the state governments reiterate the significance of a strong federal structure for effective governance. For instance, Kerala was the first state to announce an economic package of INR 200 billion (USD 2.6 billion). Yet another important initiative was taken by the state of Odisha even before COVID-19 cases started surfacing in the state. The state government reached out to people in smaller towns and villages asking everyone who had returned home since the outbreak of COVID-19 to self-quarantine at home - an estimated 84,000 people were put under home quarantine to contain the virus in the state. Furthermore, it created an online portal which all people entering the state were required to register with in order to facilitate contact tracing and health screening. Punjab Government's microcontainment and house-to-house surveillance strategy in tackling the outbreak received plaudits from Prime Minister Narendra Modi, further asking the other states to replicate the same model (The Tribute 2020).

District administrations have also been very proactive in the context of the COVID-19 outbreak and its management. The efforts and initiates of Bhilwara district administration in Rajasthan and Dharavi Model of Maharashtra have stood out. The Bhilwara district administration adopted an aggressive approach to containing the spread of this virus. More than 2.2 million people were screened in Bhilwara. The district's success is attributed to the collective efforts of dedicated local officials and has encouraged the central government to embrace the 'Bhilwara model of containment' across the country, particularly in the most-affected districts in different states of India. In Dharavi, the Brihan Mumbai Municipal Corporation started to screen people on a massive scale by visiting houses and setting up fever camps in localities. Temperatures were taken by infrared thermometers, and blood oxygen levels were read by pulse oximeters. By screening about 0.4 million people helped in taking out suspect cases - some 15,000 - from the system. Among those suspected to be carrying the COVID-19 virus, those with symptoms were quarantined and subsequently tested. The ones who tested positive were sent to hospital isolation wards; those negatives remained at the quarantine centers for 14 days. While 'test-test-test' was the mantra of the experts, on ground in Dharavi, it was 'screen-test-screen-test.' This was at the heart of the Dharavi model. It showed how smart testing could be a way out of shortages of resources and kits (Kaur 2020).

The Agra city administration's proactive tactics in categorizing cases, rigorous testing, conducting door-to door surveys, and stringent quarantine procedures was proven to be effective. The city administration adopted the policy of preparing a list of people returning from foreign tours and classifying their family and other intimate contacts. The neighborhoods in which confirmed cases resided were designated 'hotspots,' with a $3-\mathrm{km}$ radius containment zone established around them and a further $5-\mathrm{km}$ radius area designated as a buffer zone. Signifying the spirit of cooperative federalism, the Union health ministry was highly engaged in supporting the administrations' containment plans. At least 2,000 health workers were found working 
constantly in fighting the outbreak, and over 3,000 ASHA (Accredited Social Health Activist) were enlisted to help with door-to-door surveillance of over 160,000 households comprising more than 1 million city residents. This did make Agra yet another case study for other states and cities to emulate.

But the crescendo of cooperative federalism was witnessed in COVID-19 case management in Delhi. With the exponential rise in infected cases in the month of June, taking Delhi into the grip of the pandemic, both Central Government and Government of NCT, jointly and unitedly, came together in ameliorating the situations in Delhi (PTI 2020).

During the lockdown, the pandemic also provided much impetus to intergovernmental collaboration. Over the period of three months, multiple video conferences took place between the prime minister and the chief ministers. While affirming their support for an extended lockdown, states also sought for additional financial support from the central government to alleviate their own challenging fiscal situations. Time and again, Prime Minister acknowledged the collective decision-making that had gone into extending the lockdown till the month of May.

\subsection{Moments of intergovernmental contentions}

However, in between lockdown, the decision by state of Kerala to allow limited reopening of restaurants and local public transit brought it into conflict with the Union Ministry of Home Affairs which considered such measures violative of lockdown guidelines. Furthermore, in developing a more graded understanding of the COVID-19 situation across the country, the Union Ministry of Home Affairs also identified some districts where the spread was "especially serious." These places included seven districts in the state of West Bengal, Delhi, and Indore in Madhya Pradesh, Pune, and Mumbai in Maharashtra. Inter-Ministerial Central Teams were sent to these places to assess and suggest additional mitigation measures. However, the state government of West Bengal raised objections to Centre's interventions, having lack of clarity on deploying these teams under the 2005 Disaster Management Act. Without clarifying the criteria for the basis of selection of those districts in West Bengal, the state government opined those measures violative of the spirit of federalism.

During unlock 3.0, the center took a grim view of relentless restrictions issued by most of the states on interstate and intrastate movement of people and goods. Such curbs, according to the Center, only created roadblocks in economic activity as well as employment. Thereupon, Ministry of home Affairs expressed concerns to all the states and UTs over local level restrictions imposed by latter that curtailed the movements of people across various districts. The Chief Secretaries of the states were warned not to go against paragraph 5 of the unlock 3.0 guidelines of the central government and were told not to restrict interstate and intrastate movements (Express News Service 2020).

Come unlock 4.0, local lockdown could not be imposed by the states/UTs beyond the containment areas without the prior approval of MHA. Furthermore, no restrictions on the interstate and intrastate movement of the people and goods was to be strictly adhered to. This provision was also extended to the cross-border trade between states and neighboring countries. Most importantly the provision of e-permit or e-pass for the movement across the state and states was to be done away with (The Hindu 2020). 
The coordination, determination, and maintenance of standards of higher education is bestowed upon University Grants Commission (UGC) in India. In pursual of its duties and functions, in the month of July, the UGC released its guidelines for the conduct of final year examinations in the country. These guidelines were prepared by an expert committee whose perspicacity recommended the conduct of terminal semester/final year examinations, by universities/institutions by the end of September 2020 in offline (pen and paper)/online/blended (online and offline) mode. Such a decision by the UGC brought objections from multiple quarters. Not only students but many state governments condemned the guidelines and took the matter to the Indian Judiciary (NDTV 2020).

The State Governments of Maharashtra and Delhi attempted to cancel the examinations by invoking the 1897 Epidemic Diseases Act and the 2005 Disaster Management Act. However, UGC was of the view that these acts could not be invoked to make the statutory provisions of the University Grants Commissioner Act inconsequential. The decisions by respective states could have affected the standards of higher education. This was considered by the UGC as an encroachment on the legislative field of coordinating and determining the standards of higher educationexclusively reserved for Parliament under Schedule VII of the Constitution. The Supreme Court in its ruling on 28 August 2020 held that state governments would not be allowed to promote students without holding final year university examinations amid the COVID-19 pandemic. However, the Court gave states the discretion to approach the UGC for an extension of the deadline by which final year exams should be completed (Mahajan 2020).

Furthermore, the tussle between center and states continued over the conduct of medical entrance exam NEET and engineering entrance JEE. The center extended full autonomy to National Testing Agency (NTA) which is a premier, specialist, autonomous and self-sustained testing organization of central government to conduct entrance examinations for admission/fellowship in higher educational institutions (NTA 2021). NTA went on to conduct the exams after months of postponement inviting a call for further postponement from many states.

West Bengal Chief Minister Mamata Banerjee urged all Chief Ministers to collectively move the Supreme Court to postpone the NEET and JEE citing the safety of students. Thereupon, seven chief ministers of non-BJP ruled states decided to jointly move the Supreme Court on the issue. Among the chief ministers who attended the meeting were West Bengal's Mamata Banerjee (TMC), Maharashtra's Uddhav Thackeray, who is heading the Shiv Sena-NCP-Congress government, Punjab's Amarinder Singh (Congress), Jharkhand's Hemant Soren (JMM), Rajasthan's Ashok Gehlot (Congress), Chhattisgarh's Bhupesh Baghel (Congress), and Puducherry's V Narayanasamy (Congress). However, NTA wrote to the state governments to extend support in local movement of the candidates so that they could be able to reach their examination centers on time. Despite states' apprehension about the spread of infection, with judgment of Indian judiciary in its favor, NTA conducted the exams successfully. The state inadvertently supported the conduct of exams. Health secretaries were asked to help NEET officers. District Magistrates and cops were asked to ensure ease of movement and manage crowds as well as maintain law and order. The whole episode of conflict between center and state turned into a story of coordination and cooperation for protecting the future of the students (Gosh 2020). 


\subsection{Mapping the road ahead}

India is receiving appreciation worldwide for its handling of the outbreak considering its vast population density but there were criticisms regarding the hasty imposition of a nationwide curfew-like Lockdown. From federal perspicacity, the outbreak could have been dealt in a better way by consulting the states from the very beginning. Instead of an abrupt lockdown, a few days' time would have allowed industries and manufacturers to make alternative arrangements. Most importantly, migrant workers and citizens should have been given deadline to go back to their homes a time bound manner.

Moreover, it would have been more appropriate to transfer funds from PM-CARES and PM RELIEF FUND to state governments on the basis of population and intensity of COVID-19 cases in respective states. Income tax rebate should have been extended to contributions made to chief minister's fund. Most importantly, instead of having informal meetings, forum of Inter State council should have been used by setting up a standing committee to deal with it.

Furthermore, gross fiscal deficits of the states are estimated to be more than 7 percent for the 2020-2021 fiscal year (Reuters 2021). This is very much evident from the fiscal stress that the states have been grappling with, in the current cataclysmic environment. All of the states have been running through the 'scissors effect' incurring both loss of revenue due to economic slowdown and higher expenditure in containing the outbreak. COVID-19 has rendered the old-school backward-looking tax buoyancy forecasting models unreliable thus making the upcoming years for the states cumbersome. And since the growth is likely to be on downhill, tax revenues for the states are likely to be reduced in the coming years as the tax revenue fall sharply in comparison to the GDP. The existing scissors effect would only be prolonged as a result of heavy spending on health. There would also be a shoot in the contingent liabilities (guarantees). The resultant abeyance of future investment projects will eventually bring about growth losses (Mathew 2020). Thus, given the extent of economic damage that the states have already suffered in the last five months, it is more than appropriate inter alia for the Center to release past GST compensation dues as part of emergent fiscal stimulus. States' capacity to borrow should be enhanced but unconditionally.

Overall, the experience from the ongoing pandemic has only put forward the systemic importance of federal setup in the neoteric world. While federalism as an operational apparatus has been in place prior to the outbreak, its significance has increased ten-fold in recent times; eventually calling for the efficient coordination between the various levels of the government in order to tackle a cataclysm of current kind. Although there has had been instances of greater centralization with respect to the functioning of center government in containing the pandemic, nonetheless, without the coordination and cooperation between various levels of the government, containment would not have been particularly possible.

Moreover, instructions have been issued by the Center to the state governments to not pursue any secluded plans for vaccination. Such an instruction was extended to ensure effective rollout of the vaccine drive in the entire country. To authorize this, an expert committee on vaccine administration was set up by the central government that would supervise the vaccine rollout. Timely adherence of the directives was expected on the part of state government to ensure the efficacious coordination. 


\section{Rekha Saxena}

Although it may seem centralizing on the surface however, this was to pave way for proper planning, coordination and cooperation with respect to vaccine roll out. Thereupon, we could gauge another instance of cooperative federalism and cooperation between center and state in containing the outbreak (The Hindu 2020).

In one of meetings with heads of States and UTs, Prime Minister Narendra Modi himself underscored the pertinence of cooperative federalism which according to him would be seen as a hallmark in containing the outbreak in times to come. Thereupon, it is imperative that irrespective of the distribution of roles and responsibilities, all the levels of government are required to work in close coordination with each other in the spirit of cooperative federalism - a sine qua non to overcome the current crisis.

\section{Bibliography}

Business Standard, 2020. DATA STORY: India's Share of Global Active Covid-19 Cases Shrinks to $1.89 \%$ [online]. 10 December. Available from: https://www.business-standard. com/article/current-affairs/data-story-india-s-share-of-global-active-covid-19-casesshrinks-to-1-89-120121000400_1.html [Accessed 25 March 2021].

Express News Service, 2020. Unlock 3.0: Centre Asks States Not to Put Restrictions on Inter-State Movement of People, Goods [online]. The New Indian Express, 22 August. Available from: https://www.newindianexpress.com/thesundaystandard/2020/aug/22/ unlock-30-centre-asks-states-not-to-put-restrictions-on-inter-state-movement-of-peoplegoods-2186974.html [Accessed 25 March 2021].

Gosh, P., 2020. JEE-NEET: Nationwide Protest, Appeal to Supreme Court [online]. India. com, 27 August. Available from: https://www.india.com/news/india/jee-neet-nationwideprotest-appeal-to-supreme-court-ordinance-to-tweak-admission-rules-states-mull-wayout-4123115/ [Accessed 25 March 2021].

Johns Hopkins Coronavirus Resource Center, 2021. COVID-19 Dashboard by the Center for Systems, Science, and Engineering (CSSE) [dataset]. Available from: https://coronavirus.jhu. edu/map.html [Accessed 25 March 2021].

Kaur, B., 2020. At the Heart of Dharavi Model: Basic Public Health, Resolve in Community to Beat COVID-19 [online]. DownToEarth, 12 August. Available from: https:// www.downtoearth.org.in/news/health/at-the-heart-of-dharavi-model-basic-public-healthresolve-in-community-to-beat-covid-19-72771 [Accessed 25 March 2021].

Mahajan, S., 2020. States Cannot Promote Students without Holding Final Year Exams, May Approach UGC Seeking Extension of Deadline: Supreme Court [online]. Available from: https://www.barandbench.com/news/states-cannot-promote-students-without-holdingfinal-year-exams-ugc-supreme-court [Accessed 25 March 2021].

Mathew, G., 2020. Explained: How Has Covid-19 Affected Finances of State Governments? [online]. 30 October. Available from: https://indianexpress.com/article/explained/ explained-how-covid-19-has-affected-finances-of-state-governments-6906683/ [Accessed 25 March 2021].

NDTV, 2020. States Can Not Confer Degrees Without Exams: UGC to Supreme Court [online]. 19 August. Available from: https://www.ndtv.com/education/ugc-guidelinesnews-states-cant-decide-confer-degrees-without-exams-july-6-directive-not-diktat-ugc-sc [Accessed 25 March 2021].

NTA, National Testing Agency, 2021. About NTA. Available from: https://nta.ac.in/about [Accessed 25 March 2021].

PTI, 2020. People, Govts Together Attained Victory Over COVID-19, Fight Not Yet Over: Kejriwal [online]. The Hindu, 25 July. Available from: https:/www.thehindu.com/news/cities/ Delhi/people-govts-together-attained-victory-over-covid-19-fight-not-yet-over-kejriwal/ article32189894.ece [Accessed 25 March 2021]. 
Reuters, 2021. India's Fiscal Deficit Likely to Be Over 7\% in 2020/21. The Economic Times, 7 January. Available from: https://economictimes.indiatimes.com/news/economy/indicators/ indias-fiscal-deficit-likely-to-be-over-7-in-2020/21/articleshow/80152964.cms?from= mdr\#: :text=The\%20final\%20fiscal\%20deficit $\% 20$ estimates,for $\% 20$ the $\% 20$ next $\% 20$ financial\%20year [Accessed 26 March 2021].

The Hindu, 2020. State Gears Up for Unlock 4.0 [online]. 30 August. Available from: https://www.thehindu.com/news/national/andhra-pradesh/state-gears-up-for-unlock-40/ article32482356.ece [Accessed 25 March 2021].

The Hindu Special Correspondent, 2020. Vaccine Distribution: Work in Tandem with Centre, Health Ministry Tells States. The Hindu, 3 November. Available from: https:// www.thehindu.com/sci-tech/health/vaccine-distribution-work-in-tandem-with-centrehealth-ministry-tells-states/article33014514.ece [Accessed 25 March 2021].

The Tribute, 2020. PM Modi Asks Other States to Adopt Punjab's COVID-Combat Model [online]. 16 June. Available from: https://www.tribuneindia.com/news/punjab/pm-modiasks-other-states-to-adopt-punjabs-covid-combat-model-of-micro-containment-house-tohouse-surveillance-100045 [Accessed 25 March 2021]. 